\title{
Erasing high-tech barriers
}

\section{New Delhi}

INDIAN industrial research laboratories accustomed to developing technologies for a protected market are jittery following the announcement of a sweeping new Indian industrial policy, which opens the domestic market to competition, loosens official controls and gives an open invitation for investment and technologies from overseas companies and multinationals. The laboratories must now compete in order to survive.

The policy, part of a package of economic measures to rescue the crisis-ridden economy, is a departure from socialist protectionism and the tenets of technological self-reliance laid down by successive governments since India's independence in 1947. In effect, the government announcement bids farewell to earlier policies anchored on the principle of maximum support to indigenous research and development and 'selective' import of foreign technologies.

The reforms allow foreign companies to hold ownership interests of up to 51 per cent in several high-technology industries. Indian companies can now enter into technology collaboration agreements and hire foreign technicians without government clearance. Industrial licensing has been abolished for all projects except a short list of industries considered to be either of strategic value or socially or environmentally sensitive.

By dropping the fences, the government hopes to attract billions of dollars of direct foreign investment. The technologies brought by the investors will expand the production base and increase exports, thereby stimulating local industries. Many economists view the reform as a drastic but necessary step to integrate into the global economy, but it has brought India's industrial research laboratories to a crossroads.

"The new policy spells disaster to indigenous technologies in the pipeline", said an official of the National Research Development Corporation (NRDC), which is responsible for commercialization of indigenous technologies. In the past ten years, NRDC sold over 360 processes to industry. "But once the invasion [of foreign technologies] begins, we may have to close the shop", the official said. Competition is acceptable between equals, he said, but "local technologies will not even have an opportunity to stand up before those of giants like Du Pont, Dow Chemicals or Hitachi". Du Pont has announced plans to invest $\$ 800$ million in new projects in India, and Japan intends to invest $\$ 2,000$ million.

The Department of Scientific and Industrial Research, which is responsible for promoting research in industry, is also

worried. Over the years, the department has persuaded some 650 companies to establish in-house research and development units by giving them financial incentives, such as income-tax exemption. In the changed climate, the department fears the companies may decide to import the technologies instead of developing them in-house.

One of the agencies where the impact of liberalization will be seriously felt is the Council of Scientific and Industrial Research (CSIR), which presides over some 40 laboratories specifically set up to develop technologies for Indian industry. "We were prepared for a gradual reform, but it came all of a sudden", said S. K. BRAZIL

\section{Opening up to computers}

\section{São Paulo}

BRAZIL is getting close to abolishing its 'market reserve' on computers - the protectionist import ban that, critics say, has made local industries lag behind the rest of the world. A recently passed congressional bill will - if approved by the Senate and by president Fernando Collor de Mello - open up the Brazilian market after October 1992.

Collor has made it a priority to liberalize the country's economy, where the state's hand is seen almost everywhere. And nowhere has state control been more cumbersome than in the computer industry, where Brazilian microcomputers cost on average three times more than US or European equivalents.

The move to open Brazil to foreign competition has elicited very different reactions from the country's scientists. As might be expected, employees of Brazil's computer industry are among the most vocal defenders of the market reserve.

The Brazilian Society for the Progress of Science, for instance, argues that the import restrictions have created "local technologies" and provided jobs for thousands, including engineers and other electronics researchers. The society's president, Ennio Candotti, routinely denounces "American pressures" on the computer industry and other nationalist causes, such as pharmaceutical and biotechnology products patents.

But scientists who need computers and other electronic equipment for their work have other opinions. Biomedical researchers are particularly unhappy with the present situation. Not only do they not have access to good computers, but they must also struggle with the government bureaucracy whenever they need equipment that has electronic circuitry.

The usual way to circumvent the infor-
Joshi, director general of the council. CSIR, which derives 30 per cent of its budget from the sale of its technologies to industry, must now compete to survive. According to Joshi, CSIR is not threatened by competition in such areas as drugs and agrichemicals, "but we cannot compete with multinationals in areas like materials and polymers". Joshi says CSIR has no option but to reassign priorities and even abandon projects that have little chance of competing.

Joshi does not expect the impact of the new policy to be totally negative. "The fear of losing in the race will make our scientists do better", he says. Yet CSIR is hoping to seek from ministries fiscal incentives for industries that adopt CSIR technologies rather than imported ones.

K. S. Jayaraman

matics law is to resort to smuggling, and it has been said that smugglers are the real heroes of Brazilian research. There are smugglers who specialize in dealing with scientists, and some have their clientele concentrated in a single university. Estimates are difficult to make, but some say that several thousand computers are smuggled into the country each year.

Brazil's secretary of science and technology, José Goldemberg, is a strong defender of opening the market to competition. He has compromised a bit by offering to allow imports gradually, but some articles that used to be forbidden for import are now beginning to show up in local shops. When he served previously as rector of the University of São Paulo, he angered many on the staff by insisting that their work be evaluated, and now he says he wants to apply the same high standards to computer manufacture.

No one denies that opening up the market will mean that some local companies will be overwhelmed. The US chain Radio Shack is planning to open an outlet in Rio de Janeiro soon, and others will follow. One option for survival for Brazilian companies is to create joint ventures with foreign concerns. IBM already plans one such venture with a São Paulo company, SID Informática. And the Brazilian legislature is now discussing other ways to help Brazilian companies, such as tax incentives.

Even if the final legislation does not open the market entirely, it will go far in improving things for consumers - the most conspicuously absent voice in the debate. Already the timid measures taken so far date have had consequences. In an inflation-prone country where falling prices are virtually unheard of, prices for microcomputers have started to fall. 